\title{
RWA BHINNEDA THE AESTETICS OF BALINESE TRADITIONAL MUSIC
}

\author{
Pande Made Sukerta, I Nyoman Sukerna, Nanik Sri Prihatini \\ Faculty of Performing Art, Indonesia Institute of the Arts Surakarta. Ki Hajar Dewantara Road, No.19 Kentingan, \\ Jebres, Surakarta, Central Java, Indonesia
}

\begin{abstract}
Karawitan aesthetics was the "spirit" of art which was manifested in the form of three components, namely tungguhan, garap, and jengah. These three components could be regarded as aesthetic forming media which was covered by the concept of rwa bhinneda. Rwa bhinneda were two different things and functioned as elements of balance used in Balinese culture and/or Hinduism which could be used as an umbrella in studying Balinese musical aesthetics. The concept of balance could be interpreted as things that were opposite and always came in pairs. Balinese karawitan aesthetics that were opposite and always came in pairs were related to tungguhan, garap, and jengah. The aesthetic manifestations of Balinese music related to tungguhan were pemade and kantil, pengede and barangan, lanang and wadon, and ngumbang-ngisep (these terms were related to sound). The concept of balance associated with garap were polos-nyangsih, pesu-mulih, galak-manis, and ngumbang-ngisep (these terms were related to dynamics), and aesthetics that were associated with the concept jengah was the number and size of the type of tungguhan used. Jengah was a trait possessed by humans who did not want to be outdone by others. Balinese musical aesthetics could be expressed by its supporters, so that it became an aesthetic statement. In Bali there were around 48 types of Balinese gamelan, each of which had tungguhan, functions, repertoires, musicians or supporters, and different aesthetics which were manifested by tungguhan and garap factors. The 48 (forty eight) sets of gamelan consisted of 38 sets of old gamelan and 10 (ten) sets of new gamelan. The number and type of tunguhan used in each set of Balinese gamelan depended on anatomy or aesthetics. In this case, musical needed were manifested in each of the gamelan sets.
\end{abstract}

Keywords: rwa bhinneda, aesthetics, aesthetics statement, tungguhan, garap, and jengah

DOI: $10.7176 / \mathrm{ADS} / 74-05$

Publication date:July $31^{\text {st }} 2019$

\section{Introduction}

Aesthetics was the end result of media expression that was being worked on, so that it could produce or create a certain sense. Aesthetics could be said as "spirit" in artwork, especially music or karawitan. It was meant as the ultimate goal of music. Aesthetics could not be touched, seen, and sniffed, but aesthetics could be felt through hearing and / or vision. Aesthetic assessment was very subjective, depending on the ability or sensitivity of the assessor or the observer. Aesthetics was in or behind gending performance that were formed or constructed by various factors. In karawitan, an example of aesthetic manifestation was factors of tungguhan (in various types and forms), garap, and jengah. Therefore, aesthetics could be said to be the end result of a musical performance.

Aesthetics were used and produced by all types and forms of songs from various types of gamelan music in Bali, while I estimated that there were around 48 types of gamelan ensembles in Bali. The forty-eight types of gamelan ensembles, each in different forms and types of tungguhan, repertoire, function, garap, and supporting artists. In addition, the types of tungguhan used in gamelan ensembles were made of various types of materials, such as bronze, wood, bamboo, leather, iron, and brass. The size of the gamelan group in Bali was also very diverse, i.e.: "small", "medium", and "big" sizes that could be seen from the number, type, and form of tungguhan used, which would affect the number of musicians needed. Thus each song performed by the gamelan ensemble possessed or embodied diverse aesthetics. The size of the gamelan ensemble did not affect the aesthetics that were built, because each gamelan ensemble had different anatomy. For example, in wayang parwa gender gamelan ensemble, the elements that embody its beauty value were two and / or four tungguh gender wayang using two to four musicians. In gamelan gong gede ensemble, the aesthetic formation of the songs used around 39 tungguh which required around 50 musicians. The manifestation device was needed to create aesthetic values. These devices were not the purpose of the work but as a means. The instruments of aesthetic creation in Balinese music included various types and forms of tungguhan, garap, and jengah. 
Rwa bhinneda meant two different things or two opposing things which were concepts of Hindu culture and / or Hinduism which could be used as a foundation in Balinese karawitan to examine matters related to aesthetics. Being different did not mean being contradictory or opposing or hostile, but rather being a power to be able to create something solid because these differences complemented each other. In realizing these differences it was necessary to always use the concept of pairing in the same size and shape or in different sounds. Without pairing there would be no difference. By observing Balinese musical aesthetics which were formed by various numbers or types of tungguhan and garap formed by rwa bhinneda, each gamelan group had different aesthetics. It was this aesthetics that ultimately became the identity or characteristic of each Balinese gamelan group.

\section{Discussion}

\section{Rwa bhinneda}

Rwa bhinneda was a concept used in Balinese culture and/or Hinduism which was interpreted as two different things which combined into one unit, for example black and white, right-left, top-down. In the arts, especially Balinese music, it was not normal to use rwa bhinneda, but in reality the concept was in Balinese karawitan. Therefore, because Balinese traditional music did not use the concept called rwa bhinneda, the aesthetic study of Balinese karawitan would use this concept as an umbrella in studying aesthetics in Balinese karawitan.

The form of rwa bhinneda in Balinese music could be both physical and non-physical. Physical form was in the form of tungguhan types which was a means of expressing or media in presenting a song, while the non-physical form of rwa bhinneda was a sound produced from the type of tungguhan used.

Rwa bhinneda was the concept of balance, two things that were opposite and always presented in pairs. Things like this were often found in Balinese traditional music including in tungguhan.

\section{The concept of jengah}

Jengah was one of the traits possessed by humans which included arrogant attitudes, not to be outdone by their opponents. Jengah trait could be tangible in terms of musical or tone quality and could also be seen from the use of musical instruments. Jengah trait that arised from the use of musical instruments, among others, could be seen in gong kebyar performance in the form of mebarung, as happened in the Buleleng area. Before mebarung began, usually the leader assigned a member of sekeha (group) to pretend to be a trader and watched the preparation of their opponent. The disguise task would produce information about their competitors, for example when they fould out that competitors used a plain (not carved) gamelan ensemble, then the group would use the carved gong kebyar ensemble, if the number of tungguhan gangsa pemade used by their opponents was four tungguh, then they would use six or eight tungguh gangsa pemade so that the sound of the gamelan would be louder. As a result of this jengah, almost all types of gamelan gong kebyar ensembles in the district of Buleleng used six to eight tungguhan gangsa pemade in a set of gamelan gong kebyar, northern of Bali style, and most ensembles used carved pelawah.

Besides being able to see jengah, the gamelan gong kebyar ensemble in northern Bali style could also show sizes, such as pencon used in trompong, reyong, and the size of tungguhan gong. The greater the number of pencon used in the tungguhan of trompong and reyong, then the resulting tone would also be lower, as well as when the tungguhan gong size was relatively larger so the tone would also be lower. With the low sound of trompong, reyong and gong, it would produce different musicals or aesthetics. From the discussion above it could be concluded that the jengah trait possessed by humans could create aesthetics.

\section{Aesthetic manifestation devices}

As explained above, the aesthetic manifestation device in terms of type, shape, and garap was including tungguhan.

\section{Tungguhan}

The type of tungguhan that used rwa bhinneda concept was tungguhan which was paired. These types of tungguhan had the same shape but with different sizes. This type could be seen in the example as followed.

\section{Pemade and kantil}

Tungguhan gangsa pemade and gangsa kantil had the same form. The difference could be seen in the size, shape, and variation of the tone on scales. The tone of tungguhan gangsa kantil was relatively higher than gangsa 
pemade's tone (Sukerta, 2009: 192-193). The difference in the height and low tone used in tungguhan gangsa pemade and tungguhan gangsa kantil was a manifestation of rwa bhinneda concept in the realization of Balinese karawitan aesthetics.

\section{Pengede and barangan}

Pengede and barangan terms were used in certain forms and types of tungguhan, i.e. tungguhan gender wayang, trompong, and tungguhan gender rambat.

\section{Tungguhan gender wayang}

Gamelan gender wayang parwa and bebatelan (Ngramayana) ensembles used two forms of tungguhan gender wayang, namely gender wayang pengede and gender wayang barangan. The size of tungguhan gender wayang pengede was relatively larger than gender wayang barangan. Both types of tungguhan gender wayang had the same shape, but used different pitches. The tone of the tungguhan gender wayang Barangan was relatively oneoctave higher compared to the tone of tungguhan gender wayang penggede (Sukerta, 2009: 115-116). The difference in pitch height used in the tungguhan gender wayang was a manifestation of rwa bhinneda concept in the form of Balinese traditional music aesthetics.

\section{Tungguhan trompong}

The term pengede and barangan was also used to refer to the type of tungguhan trompong which was used in gamelan gong gede ensemble. A set of gamelan gong gede used two forms of tungguhan trompong, namely tungguhan trompong ageng and tungguhan trompong alit. tungguhan trompong ageng was often referred as tungguhan trompong pengede, while tungguhan trompong alit was often referred as tungguhan trompong barangan. Tungguhan trompong pengede and tungguhan trompong alit had the same form. The differences were that the shape-size, that was, the size of the tungguhan trompong pengede was relatively larger than the size of the tungguhan trompong barangan. Likewise in the the use of the musical scale, the tone produced by tungguhan trompong alit was one octave higher than the scale of tungguhan trompong gede. Meanwhile, the similarity was that each type of tungguhan trompong used the same form and the same number of pencon (Sukerta, 2009: 391392). The difference in the size of tungguhan and the musical scale used in both tungguhan was a form of rwa bhinneda concept that appeared in Balinese traditional musical aesthetics.

\section{Tungguhan gender rambat}

Tungguhan gender rambat was used in gamelan semar pagulingan saih lima ensemble. A set of gamelan semar pagulingan saih lima used four tungguhan gender rambat, which were two tungguhan gender rambat pengede and two tungguhan gender rambat barangan. Both types of tungguhan gender rambat had the same shape and tone arrangement. The difference was in the size and tone level. That the form of tungguhan gender rambat barangan was smaller and the tone was one octave higher than tungguhan gender rambat pengede. Other differences appeared in the beat pattern used (Sukerta, 2009: 111-112). The difference in the size of tungguhan and the pitch used in both tungguhan was a manifestation of rwa bhinneda concept which was seen in Balinese traditional musical aesthetics.

\section{Lanang and wadon}

The terms lanang and wadon were taken from the term used to designate male and female. The male type was called 'lanang' while the female type was called 'wadon'. Both terms were used to name the instruments in Balinese music. Tungguhan that used lanang-wadon designation was tungguhan gong and kendang. In certain gamelan ensembles such as the gamelan gong kebyar and gamelan gong gede ensembles, using tungguhan which had the title lanang and wadon in the types of tungguhan gong and kendang, there were two shapes of gong known in Balinese music, which were round and long rectangular. Gongs that were round were still called gong, while tungguhan gong which was an elongated rectangle was called gong pulu. Gong pulu used two blades which were usually made of iron and placed on a box made of wood which also functioned as a resonator. A tungguhan gong pulu used two blades that had the same pitch with a slight difference in frequency that was beaten or played by a player using a branching musical hammer. Therefore, one hit would knock two blades at 
the same time. These types of tungguhan gong pulu were used in gamelan angklung ensemble, pejangeran, pengarjaan, joged bumbung (grantang), and rindik gegandrungan (Sukerta, 2009: 331).

Gong lanang and gong wadon which were round in shape, had the same shape, but the size, sound, and waves (humming sound) produced would be different. Gong lanang had a smaller size, its sound was relatively higher compared to gong wadon's sound, and gong lanang's sound waves were faster than gong wadon's sound waves.

Tungguhan kendang lanang and kendang wadon had different sizes. kendang wadon's size was bigger than the size of kendang lanang. In addition, kendang wadon's sound was lower than kendang lanang's sound (Sukerta, 2009: 148-154). Tungguhan kendang and tungguhan gong were always placed side by side. Gong lanang and gong wadon were beaten or played by a musician, while kendang lanang and kendang wadon were each played by a musician. The difference in the size and pitch used in both tungguhan was a form of rwa bhinneda concept which manifested in the aesthetics of Balinese karawitan.

\section{Ngumbang-ngisep}

In Ensiklopedi Karawitan Bali (2009), ngumbang-ngisep term had two meanings that were to show the sound of two similar tones, with a slight difference in frequency (high low). The lower tone was called ngumbang, while the higher tone was called ngisep. The two notes were the same but the slightly different frequency was when they were beaten at the same time would cause a wavy sound or waves. Ngumbang-ngisep was found in tungguhan that used blades (Sukerta, 2009: 263). The difference in frequency with the same tone was the emergence of Rwa bhinneda concept in the form of Balinese karawitan aesthetic.

\section{Garap}

\section{Polos-nyangsih}

Polos and nyangsih (nyandet) were terms related to garap, which was to work on bantang gending (balungan in Java) by using various beat patterns. This combination of polos and nyandet would result in a link or candetan. Polos beat was a beat pattern which was closer to bantang gending (on beat), one of the beat pattern elements which formed the link or beat of one of the tungguhan with the final tone (seleh) of bantang gending (Sukerta, 2009: 295). Nyandet beat was a beat with a pattern that was further than bantang gending (off beat) which was also one of the beat pattern elements that form links or candetan (Sukerta, 2009: 316).

The musician who presented polos pattern was called pemolos, while the musician who presented nyandet or nyangsih beat pattern or was called penyandet or penyangsih. Polos and nyangsih beat patterns were used in the types and forms of tungguhan which were paired as such as tungguhan gangsa pemade, gangsa kantil, and gender wayang.

When working on a composition, the presentation of nyandet beat pattern was relatively far from the melodic flow of bantang gending that was performed. The volume of penyandet beat was relatively louder than pemolos beat. This distinction in volume would show better gending performances (Sukerta, 2009: 316). The existence of polos and nyandet beats were a form of rwa bhinneda concept in the aesthetic manifestation of Balinese karawitan.

\section{Pesu-mulih}

The term pesu-mulih consisted of two words that were pesu and mulih. Pesu meant to go out while mulih meant to go home. Among musicians in Balinese traditional music, the term pesu-mulih was used to refer to song sentences from a composition or tone. Pesu was used to refer to the sentence of a song that had mild pressure (not seleh or padang, in Java) and 'mulih' was used to refer to a song sentence that had a heavy pressure (seleh or ulihan: in Java). The existence of this pesu-mulih which was related to the flow of melody was a manifestation of rwa bhinneda concept in the form of Balinese traditional music aesthetics.

\section{Galak-manis}

Galak-manis were related to dynamics, namely hard-soft (volume) and fast-slow (tempo) in a traditional composition performance. Galak-manis were a volume and tempo usage unit in a composition. In traditional composition performances, galak-manis were one of the important elements to be able to bring up the song impression contained in it. The use of volume and tempo of a song was presented based on the character of the composition or the composition section. What was meant by the song character was, for example, there was a composition section that when served with a fast tempo, felt less "good" or vice versa. Thus the use of volume 
and tempo in a traditional composition performance was interpreted and at the same time tried (done by experiment). In addition, the use of tempo and volume was based on the agreement of a group of musicians (sekeha). Therefore, it was often found that the same composition would be presented with a tempo arrangement (galak-manis) that differed between one and the other (Sukerta, 2009: 84). The existence of this galak and manis which was related to dynamics was a manifestation of rwa bhinneda concept in the form of Balinese musical aesthetics.

\section{Ngumbang-ngisep}

The definition of ngumbang related to garap was a form of dynamics that showed the combination of volume settings in a composition on a traditional music performance. Loud volume was called 'ngumbang' or nguncab, while soft volume was called ngisep (Sukerta, 2009: 263).

Maintaining the dynamics associated with volume had a strategic position in maintaining the dynamics of a composition, because it would give a spirit to the composition presented. The difference in the volume of ngumbang and ngisep related to dynamics was the realization of rwa bhinneda concept in the aesthetic form of Balinese karawitan.

\section{Aesthetics in artists' expressions}

Aesthetics which could be referred as "spirit" in a work of art, could be transformed not only by various factors related to music, but also through statements or expressions. Sukerta (2013: 129-134) mentioned several statements by Gede Manik (deceased) related to aesthetics, as followed.

Bayu sube seger buin siamin, It was Balinese language, literally meant that the power had been watered. This expression showed musicians' spirit in presenting a repertoire that matched its character. For example, when presenting the Tarunajaya dance composition, the musicians of gong kebyar Buleleng (north area of Bali) appeared enthusiastic because Tarunajaya dance performances were presented with a fast tempo and loud volume.

De patuhange Duren Buleleng ajake Duren Badunge. It meant do not equate durian fruit from Buleleng Regency with durian fruit from Badung Regency. These expressions related to gong kebyar Buleleng style (North area of Bali) with gong kebyar Badung style should not be equated.

Pade ngabe sikut. It meant that each style had a different "size", especially in terms of volume, speed, and beating technique.

Gong kebyar Buleleng style was considered the same as lalahe tabie (spicy flavor of chili), while the gong kebyar south of Bali style musical performance was likened to lalahe merice (spicy flavor of pepper).

Another aesthetic expression often expressed by Balinese karawitan artists, including:

\section{Jaan sajan gendinge}

This expression was often heard when a musical performance was finished. The impression, audience was very satisfied listening to the musical performance. The expression statement was a sign that the composition presented was pleasant and good.

\section{Manis sajan gendinge}

The term manis was used to express the feelings captured from a composition. A song that had a manis impression, for example, was caused by the composition using a high pitch area, then followed by tungguhan suling and rebab (Sukerta, 2009: 233).

\section{Wayah sajan gendinge}

The phrase 'wayah sajan gendinge' meant 'how old was the composition', which meant that the composition presented had a very old impression (roso, Bali). The example was in the gong gede (lelambatan) compositions. This impression of this kind of wayah composition was partly due to the fact that the song used a lower tone area, and was determined by the flow of the song and its musical rhythm (Sukerta, 2009: 402).

\section{Wayah sajan gegebuge}

The phrase 'sajan gegebuge' meant 'the punch was very old'. This was related to the fact that the garap used to present the song created an old impression (wayah). Examples of the garap included the beat of kendang pepanggulan and the beat of tungguhan trompong. The type of kendang beats which had pld impression was 
kendang beats that was beaten between taps, including flat-beat kendang (no variation), and used the 'tet' sound caused by kendang lanang and kendang wadon's beat by closing or pressing the tebokan Kendang on the left side while hitting the right hand side by using the panggul (Sukerta, 2009: 402). Tungguhan trompong beats that feels old was caused by the good closing when hitting or playing tungguhan Trompong and used not too many beats when playing the composition.

\section{Closing Statement}

Aesthetics was a "spirit" of art, especially karawitan which was a musical composition formed by various types, forms of tungguhan, garap, and jengah. Aesthetic accomplishment of a musical composition was not arranged by the number and type of tungguhan used, but was determined by the completeness of the musicals arranged. Each gamelan ensemble had its own anatomy (necessity) of tungguhan that was used as an aesthetic manifestation.

Aesthetics could be viewed from the point of view of rwa bhinneda concept which considered that the form of beauty could vary but was in one unit. Thus culture and / or religion were positioned as umbrellas to create aesthetics.

Tungguhan functioned as a means of expressing, mostly in the form of pairs, such as pemade with kantil, gender wayang pengede with gender wayang barangan, lanang with wadon in tungguhan gong and kendang. In garap, it was materialized through polos forms with nyangsih or nyandet, galak with manis, and ngumbang with ngisep which were related to dynamics. Jengah was manifested in the size and number of types of tungguhan that were used. Besides being materialized, aesthetics could also be expressed. In relation to rwa bhinneda concept, it could be said that rwa bhinneda concept could create linkages or cacandetan, ngumbang-ngisep, and dynamics. It was this aesthetics that would manifest the identity or characteristics of each gamelan ensemble.

\section{References}

Ahimsa Putra, Heddy Shari. 2002. "Tekstual dan Kontekstual Seni Dalam Kajian Antropologi Budaya”. Makalah disampaikan pada Serial Seminar Internasional Seni Pertunjukan Indonesia 2002-2004, tanggal 3 dan 4 Juli 2002 di Gedung Teater Tertutup Sekolah Tinggi Seni Indonesia (STSI) Surakarta.

Djelantik, A.A.M. 1994. "Peranan Estetika dalam Perkembangan Kesenian Masa Kini”, dalam Mudra, Jurnal Seni Budaya No. 2 Th. II, Februari 1994. Denpasar: UPT. Penerbitan Sekolah Tinggi Seni Indonesia (STSI) Denpasar.

1999. Estetika Sebuah Pengantar. Bandung: Masyarakat Seni Pertunjukan Indonesia.

Halliday, M.A.K. dan Ruqaiya Hasan. 1994. Bahasa, Konteks, dan Teks. Aspek-aspek Bahasa dalam Pandangan Semiotik Sosial. Diterjemahkan oleh Asrudin Barori Tou dan M. Ramlan. Yogyakarta: Gadjah Mada University Press.

Kayam, Umar. 1981. Seni, Tradisi, Masyarakat. Jakarta: Sinar Harapan.

Mudji Sutrisno. 1999. Kisi-kisi Estetika. Yogyakarta: Kanisius.

1993. Estetika Filsafat Keindahan. Yogyakarta: Kanisius.

Prihatini, Nanik Sri. 2005. "Sanghyang Dedari : Kajian Teks dan Konteks", dalam Jurnal Panggung Jurnal Ilmiah Seni dan Budaya STSI Bandung Vol.18. No. 1 Januari-Maret 2008 ISSN 0854-3429

.2008. "Eksistensi Pertunjukan Kuda Kepang Di Lereng Gunung Sumbing Jawa Tengah Menuju Ke Sebuah Identitas", dalam Jurnal Greget Jurnal Ilmu dan Seni Jurusan Tari ISI Surakarta Vol.07. No. 1 Juli 2008 ISSN 1410-9700.

2017. “Memaknai Air Dalam Kehidupan Dari Perspektif Hindu Dan Seni” yang dipresentasikan dalam Seminar Internasional di Universita Sebelas Maret Surakarta.

.2017. "The Role Of Aesthetic Authority In The Surakarta Style Serimpi Dance” Asian Journal of Social Sciences \& Humanities (AJSSH) ISSN: 2186-8492, ISSN:2186-8484 Print Vol.6 (4), November 2017.

Rai S., I Wayan. 2001. Gong Antologi Pemikiran Seni Budaya. Denpasar: Bali Mangsi Press. Sahman, Humar. 1993. Estetika Telaah Sistemik dan Historik. Semarang: IKIP Semarang Press.

Sukerna, I Nyoman. 2007. "Swara Genta Pinara Pitu: Mitologi Pelarasan Nada Gamelan Semar Pagulingan". 
Vol. 7 No.2 Jurnal KETEG, Surakarta: Jurusan Karawitan ISI Surakarta .2008. "Musikalitas Gamelan Jegog Bali”. Jurnal DEWARUCI, Surakarta : Pascasarjana ISI Surakarta .2006, "Gender Wayang: Barungan Gamelan Bali Kelompok Tua". Vol.4 No.1 Jurnal DEWARUCI, Surakarta : Pascasarjana STSI Surakarta

Sukerta, Pande Made.2016. Gong Kebyar Yang Tidak Ngebyar, Surakarta: ISI Press Solo. .2009. Ensiklopedi Karawitan Bali Edisi Kedua, Surakarta : ISI Press Solo.

.2009. Gong Kebyar Buleleng Perubahan dan Keberlanjutan Tradisi Gong Kebyar, Surakarta : Program Pascasarjana bekerjasama dengan ISI Press.

.2010. "Kreativitas Seni Berbasis Lokal" Makalah yang dipresentasikan dalam rangka Kuliah Umum Metode Penciptaan Seni di Institut Seni Indonesia (ISI) Denpasar tanggal 30 September 2010.

.2010. Tetabuhan Karawitan Bali I, Surakarta : ISI Press Solo.

.2011. Belajar Rebab Bali Edisi ke-2, Institut Seni Indonesia (ISI) Denpasar bekerjasama dengan Kementerian Kebudayaan dan Pariwisata Republik Indonesia, Surakarta : ISI Press.

.2013. Canang Sari (Kumpulan Makalah 1977-2013), Surakarta: ISI Press.

.2011. Metode Penciptaan Karya Seni (Sebuah Alternatif), Kementerian Pendidikan Nasional, Program Pascasarjana Institut Seni Indonesia (ISI) Surakarta, Surakarta : ISI Press Solo. 